\title{
Impacts of Conflicting, Institutional Mandates on Water Security: Pathways for Water Sector Development in Turkana County, Kenya
}

\author{
Benard Oula Muok ${ }^{1}$, *, Ong'ech Dennis Onyango² \\ ${ }^{1}$ Directorate of Research, Innovation and Partnerships, Jaramogi Oginga Odinga University of Science and Technology, Bondo, Kenya \\ ${ }^{2}$ Reach Kenya Programme, University of Nairobi, Nairobi, Kenya
}

Email address:

bmuok@yahoo.com (Benard O. M.), ongetch@yahoo.co.uk (Ong’ech D. O.)

${ }^{*}$ Corresponding author

\section{To cite this article:}

Benard Oula Muok, Ong'ech Dennis Onyango. Impacts of Conflicting, Institutional Mandates on Water Security: Pathways for Water Sector Development in Turkana County, Kenya. Science, Technology \& Public Policy. Vol. 4, No. 2, 2020, pp. 44-53.

doi: $10.11648 /$ j.stpp.20200402.11

Received: May 11, 2020; Accepted: May 27, 2020; Published: June 4, 2020

\begin{abstract}
His paper elucidates the interactions between different formal and informal institutions in water governance through a case study of water distribution in Turkana County. Like other counties in Kenya, the governance of water in Turkana is currently taking place amidst a process of political devolution, changing policies and laws, and complex socio-cultural changes brought about by changing the environment. This contributes to re-shaping patterns of governance over water resources in new and somewhat unpredictable ways. Further, the different governance systems often result in overlapping authorities. These overlapping authorities often result in results in tensions between the involved institutions. At some point, there are usually conflicts of interest over governance issues, authority, strategic planning and management of programs, projects or activities. Such administrative wrangles cause enormous problems and delays in service delivery; hence citizens suffering water insecurity. The study assesses the roles of both formal and informal institutions in addressing water insecurity and how much these institutions are involved in policy processes, decision-making and implementation of strategies and programs. The results from this study indicate that institutional conflicts result from poor strategic planning, failure to align national and County policies, delayed adoption of devolution principals and political interests which have significantly compromised water service delivery thus water security in Turkana. Such factors have resulted in institutional overlaps, financial challenges, insufficient management capacity within institutions, policy and operational gaps, human resource capacity, poor evaluation and monitoring gaps.
\end{abstract}

Keywords: Water, Governance, Devolution, Conflicts, Overlapping Authorities, Policy

\section{Introduction}

This paper investigates the impacts of conflicting institutional mandates affecting water security delivery in Turkana County. The study assesses the roles of both formal and informal institutions in addressing water insecurity and how much these institutions are involved in policy processes, decision-making and implementation of strategies and programs. There is increasing awareness of how resource governance policies and programs, including water, access to natural resources and climate change policies, often become an arena for struggle over authority as well as state-citizen relations $[1,2]$. The Kenyan water sector is yet to find its proper operational balance following the devolution process. The sector is still experiencing many institutionally related challenges such as corruption, inadequate funding and overlapping mandates irrespective of the many sectoral reforms [3]. It is against this background that this study was designed. The study aims to critically analyze these institutional challenges slowing down sectoral growth and recommend effective measures to address them. The key question the study sought to address is "how does water governance evolve along with political and policy changes, and with what outcomes to water security in Turkana county?"

We approach water resource governance as interacting processes of decision-making regarding how resources are 
used, which in the current context include a water source, water distribution, use and monitoring. Government actors are usually vested with the formal authority for governing a particular territory, resource or sector through programmes, strategies, policies as well as rules and regulations. However, governance signifies more than what the government does; it also includes how various institutional arrangements and norms govern systems. It also includes customary law, norms and practices between groups, civil society, and private sector [4]. Finding a hybrid mode of governance across the state-market-community often emerge in some areas [5]. Besides, authority relations are a crucial component of how institutions and resource governance function and evolve. For example, [6] showed how climate change adaptation policies in Nepal, power and politics often play out in struggles over governing resources, shaping the outcomes of policies and climate actions.

Furthermore, various actors in resource governance use policies or their lack thereof to stake a claim of authority, as well as assert rights as political and cultural citizens. In this study, we see authority as relations that are constituted by daily interactions and decision-making [7]. This relation is enacted by someone/actor claiming the authority to decide on water resources, and whether such decisions are respected or contested by others.

Kenya has been undergoing through enormous political changes brought about by the promulgation of a new constitution in 2010, which brought the evolution of developed system of government. The changes in the political landscape have been associated with competition for political positions at different levels from the national to the local level. Besides, it has also created tension between the different levels of the government, especially in resource allocation and governance. [8] warns that decentralization reforms in many parts of Africa which were meant to bring services closer to the people and better efficiency in resource governance may not necessarily lead to more efficient or equitable use and management. In Kenya, for example, the shifts in decision-making power over budget allocation and some aspects of natural resource management from national to the county level actors has not only altered authority relations, with both overlaps and shifting authorities but also at times gaps in authority, as well as tensions as actors seek to clarify and strengthen their positions to get more resource over the others [9].

Like other developing countries, countries, Kenya still faces increasing water security risks [10]. Many counties in Kenya are struggling with WASH problems attributed to by inadequate infrastructure, insufficient funds, and poor storage, administrative and human resource issues. Kenya is a water-scarce country with current renewable freshwater potential standing at $650 \mathrm{~m}^{3}$ per capita per annum. This is much lower than the global threshold of "renewable freshwater potential less than $1,000 \mathrm{~m}^{3}$ per capita per annum" for a country to be considered as water-scarce [11].

Water insecurity is a great challenge in many counties in Kenya, especially the arid and semi-arid regions. These are regions that experience incredibly variable rainfall, yet they support almost a third of the Kenyan population [10]. Even with devolution of the water sector, its development in many counties have not yet optimized in terms of performance to offer competitive service delivery and provide operational systems that can ensure water security to Kenyan citizens. Performance and development of water sector relies entirely on effective and sustainable strategic planning, efficient institutional coordination, proper monitoring and evaluation among many other factors [12].

Water stress is a challenge to economic development not only for the arid and semi-arid lands (ASAL) regions but also areas having reasonable amounts of water, which is extensively abstracted for economic activities [13]. The high competition between various water user groups has resulted in water insecurity, and this is a situation worsened by weak institutional systems that that are unable to offer services due to inefficiency. Further, the existing information gap hinders the provision of strategic solutions to water problems. All these challenges, combined with financial challenges, corruption, biased allocation of funds, weak monitoring and enforcement systems and conflicting institutional roles in managing water resources, only worsens water security in Kenya.

Access to safe and sufficient water, is recognized by the Constitution of Kenya 2010 as a fundamental human right. Further, the Constitution assigns water supply and sanitation provision as one of the devolved roles of the county governments. Institutional performance in terms of service provision was expected to improve significantly as a result of devolution, but this has been challenged by the dynamism of decentralization process, as it requires more time, financial commitment, and right strategies. Devolution in Kenya presented an opportunity to solve the corruption trends, which resulted from the domination of the political arena by certain ethnic groups, thus inequity in resource distribution [14].

Devolution aimed to bring people closer to the state as it provides democratic and development benefits and ensures everyone's voice and authority is recognized in political systems as they provide sustainable solutions to local problems [15]. This is sadly not the case; Kenya is in a situation where water service provision has been politically interrupted, and decision-making and distribution of funds are inconsiderate of the real problems on the ground. Devolution has modelled new winners and losers in terms of economic growth and sectoral development, thus exacerbating existing social cleavages at local levels [15]. Though the principle behind devolution was to bring institutions closer to citizens hence an opportunity to address water insecurity by reducing the risks at scale, in the absence of proper institutional governance and coordination, there has been duplication of activities, which has to some point failed [10]. Furthermore, the national government "instrumentalized their design and implementation for their purposes and further minimized the power and resources of decentralized administrations" [14]. Due to the delayed transfer of authority, the county governments rely entirely on the national government for 
some decisions to be made. Moreover, counties lack the capacity or are not mandated to govern some sectors hence difficulties in implementing decentralization [14].

It is evident from this study that Turkana is water-stressed and faces acute water shortage all year round irrespective of the many institutions working on water sector development in the region, thus vulnerability of community members to water problems, especially during drought situations. Such problems result from institutional challenges such as poor planning both at County and national levels and inefficient institutional coordination by the responsible institutions in authority [12]. The study finds that existing institutions are working in silos and most of the programmatic responses to water problems are implemented without sufficient scientific evidence, thus the failure of water projects in providing the solution. This study unveils that many boreholes have been dug in Turkana under high budgets, but most are either dry or salty, begging the question as to whether sufficient pre-feasibility tests and hydrogeological studies were done before drilling the boreholes. It calls for strategies that are fit for purpose and pro-poor plans to ensure sustainable solutions are provided to address the water insecurity.

\section{Materials and Methods}

\subsection{Study Site and Approach}

Turkana County is an arid and semi-arid county characterized by warm and hot climate. The temperatures range between $20^{\circ} \mathrm{C}$ and $41^{\circ} \mathrm{C}$ with a mean of $30.5^{\circ} \mathrm{C}$. The rainfall pattern and distribution is erratic and unreliable, both with time and space. There are two rainfall seasons. The long rains (akiporo) usually occur between April and July and the short rains between October and November and ranges between $52 \mathrm{~mm}$ and $480 \mathrm{~mm}$ annually with a mean of $200 \mathrm{~mm}$. The driest periods (akamu) are January, February and September. The rainfall is distributed on an east-west gradient with more rainfall in the western parts and other areas of higher elevation. The rainfalls are brief and come with violent storms resulting in flash floods. The surface runoff and potential evaporation rates are incredibly high.

The primary sources of water in rural parts Turkana County are unprotected dug wells, streams, and boreholes. More than half $(61 \%)$ of rural households in the County use unimproved water sources with the majority relying on unprotected wells and streams [16]. Full water resources potential for the County is not yet established as no proper monitoring installations exist in permanent rivers. Access to water significantly affects food security due to its impact on the key sectors such as livestock production, crop production, sanitation, health and nutrition, and therefore hampering human productivity.

The community accesses surface water from the seasonal rivers during the rainy season, and also accessed by digging holes in the sandy areas of riverbed during the dry season. This water is not portable, and hence the communities are exposed to water-borne diseases. Despite the dry nature of the County in most parts of the year, there are a few permanent rivers including the Turkwel River, Kerio River, Elelea irrigation canal, Nabwanyang River and Nawoyawoi River.

\subsection{General Strategy}

This study was conducted using a qualitative approach. It involved the use of case studies focusing on Turkana County. Case study approach was found to be more relevant because the method provided valuable insights into the local perspectives of study populations and allows the researcher to go into an in-depth discussion with the key actors [17]. Moreover, this study aimed to understand impacts of conflicting institutional mandates on water security of the society which qualitative method assists in getting more insights and gathering more evidence since it involves matters of grave concern which may not be available or can not be easily accessed. The challenge is that it is often hard to know how far one can generalize from one case. To address this, the study did triangulation of information received from different sources to be able to conclude.

Further, qualitative method is useful in identifying intangible factors, such as social norms, socioeconomic status, gender roles, ethnicity, and religion, whose role in the research issue may not be readily apparent" [17]. The method allows the use of open-ended questions with an opportunity to deeply probe and have the participants give their answers without feeling coerced into giving answers they don't understand well [18]. It is a model that allowed the study to have productive discussions with respondents on research questions. [17] explain that qualitative methods are typically more flexible - this way, they allow greater spontaneity and adaptation of the interaction between the researcher and the study participant.

\subsection{Data Collection}

Data collection was done through household interviews which involved interviewing of water users, key informant interviews and document reviews. Strategic sampling strategy was used to select respondents and documents for review as it ensured the right people and documents that gave relevant views and information regarding the research questions. Further, the analysis was done by looking into themes in the data that gave insights into research questions.

During the interviews and document reviews, strategic sampling was applied to ensure relevant respondents and documents are selected for the study to get correct views and opinions. The survey targeted 100 households (water users) residing in 5 villages in Turkana Central (Kanamkemer and Township wards). This worked out to approximately 20 interviews per village. In the densely populated villages, 10 households were interviewed whereas in the medium densely populated 5 households were interviewed, while in the sparsely populated villages, 2 households were interviewed. The choice of five villages was made because these villages are more central and accessible and further host Lodwar Township that is considered a small town in a fragile land. In this region, surface water is unavailable, and groundwater 
quality is poor and low in quantity, yet the population has overly increased over the few years since devolution commenced. Finally, the choice of five villages was also driven by the unavailability of funds to cover the extensive parts of Turkana.

For the villages in the densely populated areas, every $5^{\text {th }}$ household in each village was interviewed. In the medium densely populated villages, every 3rd household was interviewed, and in the low to very-low-density villages, every 2nd household in the village was interviewed. Data collection was done using questionnaires for water users (households) and checklist key informant interviews. For the water users, questionnaires were administered to the household heads. In contrast, the checklist for the key informants were administered and responses recorded using audio recorder after which transcriptions were done for analysis. The water user interviews and key informant interviews allowed one on one engagement with respondents hence an opportunity to interact with individuals on their experiences and get first-hand information. Even-though the study engaged with local community members who are the water users, the main challenge was time and availability of funds to engage with as many water users as possible. This was addressed by ensuring the sample frame was as representative as possible. The key informants included: county government leadership, the non-governmental organizations, and managers from various institutions in the water sector.

Several data search methods were applied to gather secondary data from media, government institutions, development partners and academia. These included publications, articles, books, reports, journals, policy documents and blogs. These helped much in understanding institutional issues affecting the water sector and providing insights on some of the sustainable pathways for water sector development.

\subsection{Transcription of Key Informant Interviews}

This study adopted a verbatim transcription for the data collected from the key informant interviews. This allowed the study to be able to get a good sense of how many examples are available in the data collected and further shows how prevalent the study focus is [19]. It also provides the study with sharable records of what the respondents said during the interviews. The verbatim transcription allowed the study team to keenly listen to all kind of emotions displayed in the audio recorded file as these are indicators of how the respondent feels about their experience and feeling about the water security situation.

\section{Results and Discussion}

Data analysis was carried out in phases for the information obtained from the water user interviews, key informants and the existing literature on water issues. Themes were developed from the research questions, which aimed to understand the impacts of conflicting institutional mandates before analyzing the data. The themes also focused on the various pathways to water sector development. The themes are presented in the table below.

\subsection{Analysis of Themes}

Table 1. Terminologies used.

\begin{tabular}{|c|c|}
\hline Terminology & Description \\
\hline Institutions & The stakeholders involved in the sector (Formal and Informal) \\
\hline Policies & The existing water sector policies \\
\hline Water Security & What is the status \\
\hline Mandates & Existing authorities within and outside Constitution \\
\hline Formal \& Institutions & Which ones are in existence, and what are their roles? \\
\hline Strategy & Strategic needs and plans in existence \\
\hline Authority & Control and access of water resources \\
\hline Impacts & Positive and negative effects of decisions \\
\hline Pathways & Models for change/ solutions \\
\hline Development & Activities to achieve positive change \\
\hline Jerry can & The number of 20-litre jerry cans used at household level \\
\hline Cost & The cost of water \\
\hline Bills/ Tariff & The fees paid by water users to LOWASCO \\
\hline Storage & Water storage facilities at household level \\
\hline Kiosk and vendors & Existence of other water supply avenues such as vendors and kiosks \\
\hline Quality and Quantity & The quality and quantity of water available \\
\hline Demand and Supply & The changes in demand and supply over time \\
\hline
\end{tabular}

First, the themes captured in the above table were searched in the transcripts from the interviews, notes and specific documents and further recorded. In the following analysis stage, the records obtained from the themes in the first stage were categorized to generate a list of each theme and its transcript record and the specific document where it was generated. This process aimed to generate broader perspectives on water sector institutions, how they interact and their mandates. Finally, the transcript records were synthesized to gather more insights, new ideas, points, 
patterns or elaborations that can answer the research questions.

Water user interviews were carried out in between January and February 2019 with the aim of assessing the household water situation in terms of water access, quality, household income sources and other socioeconomic issues that define water security situation in Turkana County. The process targeted 100 households (Water Users) living in Turkana County with a focus on Turkana Central Sub-County (Township and Kanamkemer Wards).

Table 2. Summary of water users' response.

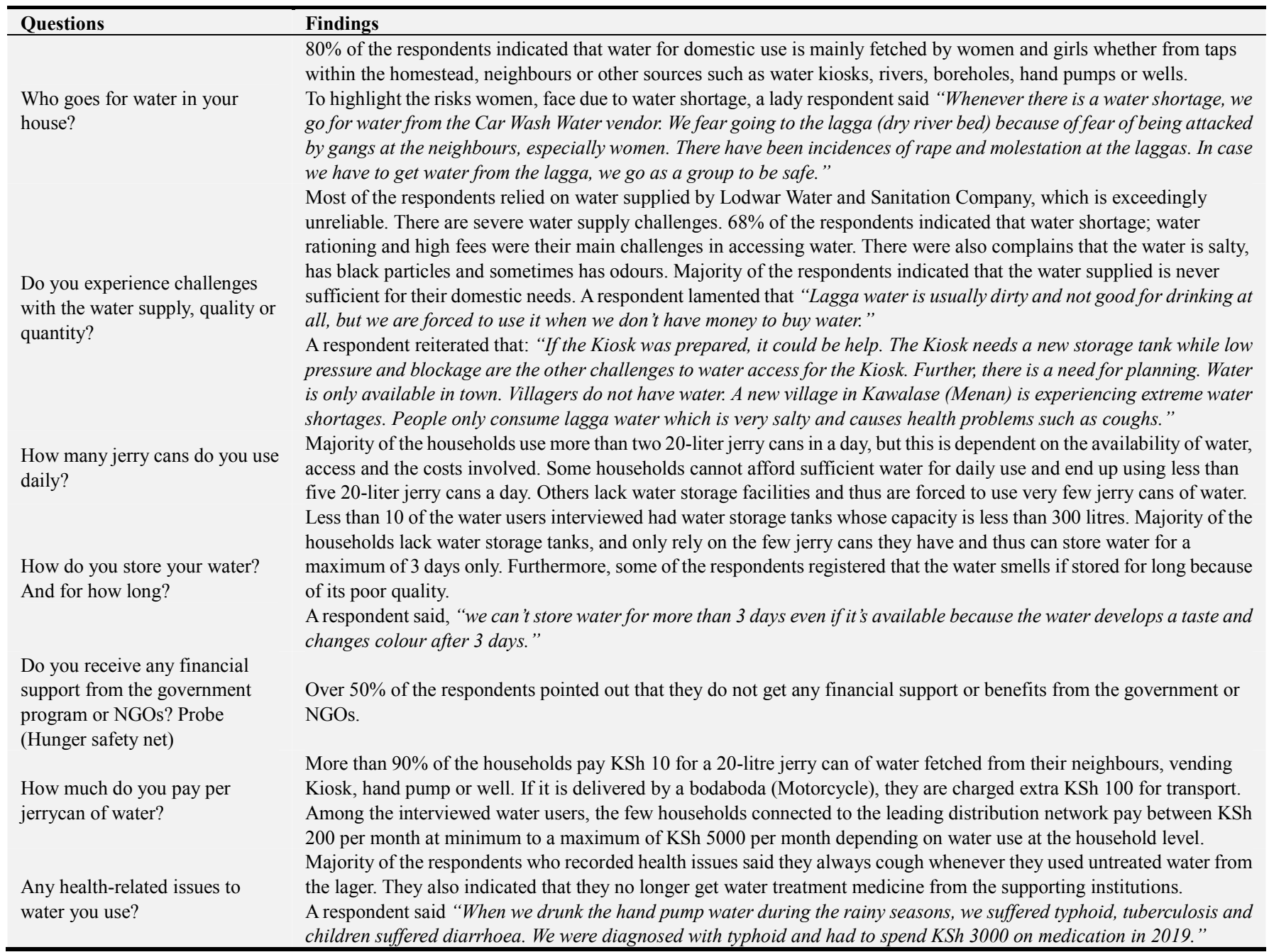

\subsection{Access to Water Resources and User Experience}

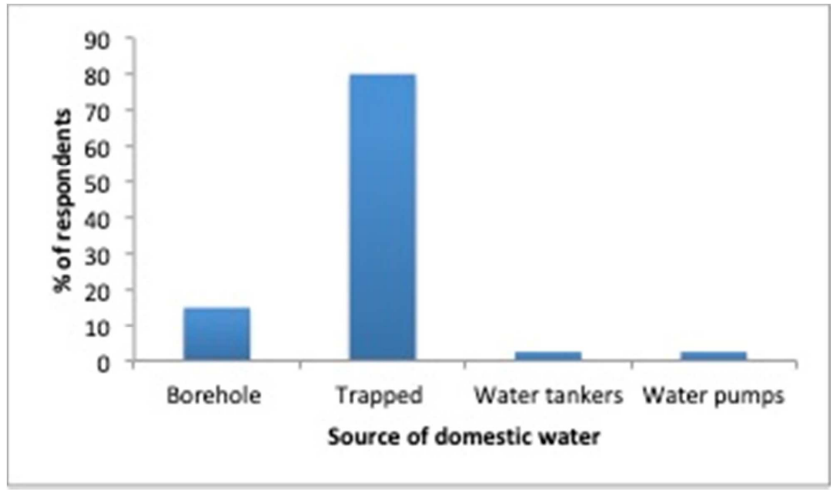

Figure 1. Source of water for domestic use.

In terms of access to water resources, majority $64 \%$ of the residence of Lodwar town indicated that they get their water from the LOWASCO taps while $12 \%$ of the respondents said they rely on borehole water. The rest accessed water from water pumps and water tankers, respectively (Figure 1).

In the attempt to understand the water-related challenges facing households of Lodwar, $46 \%$ of the respondents interviewed indicated that high fee charged was is the main challenge, this was followed by $12 \%$ who indicated that water shortage as the main problem. The other problem was identified as water rationing, which was scored by $10 \%$ of the respondents. The other problems pointed out by residence include distance to the water point, obtaining a connection to the main distribution line and dirty water (Figure 2).

The study found out that Turkana being a water-scarce region, households rely much on groundwater which accessing is a challenge due to the high drilling costs thus high charges to consumers by the water supply companies to 
recover the costs incurred after drilling.

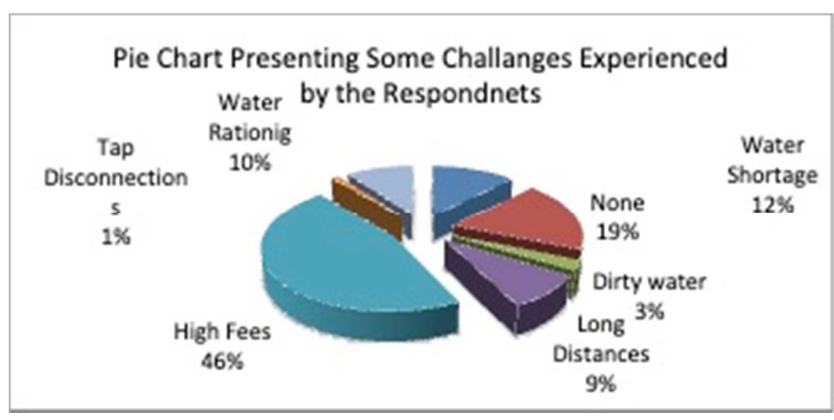

Figure 2. Challenges experienced by water users.

\subsection{Policy Issues}

Water provision is one of the roles of a devolved system of governance as defined by the Constitution of Kenya 2010. To achieve this mandate, the County Government of Turkana provides five main functions including provision of water services, water resources conservation, water pollution control and identification and construction of boreholes [20]. The County's mandate is ensuring that rural and urban parts of Turkana get served effectively. However, as can be seen by the number of households accessing water, achievement of this mandate is faced by several challenges, which ranges from policy to instructional issue, including governance and capacity. Turkana is tentatively guided by a draft water and sewerage services sector policy developed in 2016. To date, the draft has not been completed creating a gap in the implementation of the country water governance mandate. One of the KIIs pointed out that:

"The stakeholders worked hard to develop the policy which was later was approved by the cabinet and pass to the county assembly where it is still stack to date because of internal intrigues and conflicts of interest. It is taking so long. So, with that, the policy still missing, it means we lack the coordination aspect. So, all the projects being done by the county government are based on a gentleman's agreement because there is no formal basis." Key informant, 2019. Further another Key Informant mentioned that delay in policy approval and implementation has been as a result of political greed by some county politicians who demand large amounts of facilitation fee before they can approve policies.

Delayed approval of the policy has had an adverse impact on water governance in the County as and further slowed down the implementation of programs at the county level because of the absence legal framework to guide processes. Currently, the County's water budget primarily focuses on operational issues rather than strategic management [20]. The unavailability of policy has an impact on the long-term development of the sector. Moreover, lack of domestication of national policies and strategies into county contexts and low expertise in water policy formulation further complicates the problems. Poor access or inexistence of information and research systems that enable data collection at county levels hinders the analysis of national and County policies, plans and strategies on water sector management [21].
Further, overlapping authorities was identified by the respondent as a cause of confusion and tensions in the governance of the water sector. A respondent highlighted that:

"Given that there are many institutions mandated to govern water sector in various capacities, our job and performance is in a way affected. We have the Ministry of Environment, Water Resources Authority, local water companies, Water Regulation Board, Water Appeals Board, Water Works, Water Services Trust Fund and Water Services Board. All these offices deal with water issues, but terms are not clear as such! As you know, water is a devolved function, but some bodies are still being fully managed by the National Government like the WRA, Water Board, etc." (Key Informant, 2019).

More irony is, though yet to be passed, there are already some weaknesses inherent in the policy. For example, the policy provides no precise mechanisms on how technical support will be provided to public institutions to ensure they get water services. Further, the livestock sector, which is a key source of livelihoods in Turkana, is not sufficiently addressed by the policy. Further, the institutional design does not outline measures for addressing disaster and flash floods, yet Turkana County is vulnerable to such climate risks. Lack of coordination systems between the national government and the county government is a potential source of tension during implementation [20].

To address these policy issues and enhance service delivery, the County Government of Turkana needs to sensitize the county assembly and train the existing water sector committees on the importance of having a water policy in place. The county executive committees' members need to be trained on various strategies for investment planning so that they can design effective strategize and prioritize on a need basis without over-reliance on external expertise. Further, there is a need for the county government to take up policies that devolve roles and responsibilities to autonomous agencies and communities [20].

\subsection{Formal and Informal Water Institutions}

Both formal and informal institutions are involved in water sector governance in Turkana, but different sectoral laws and regulations define different capacities and authorities and. While formal institutions are legally formed, the informal institutions may be integral to the political and social processes but are very critical in addressing water issues. Turkana has several institutions working to address water in (security). The study found out that the County has more than 60 institutions working in the water sector [22]. The formal institutions include: Ministry of Environment, Water and Mineral Resources as the lead institution on water services provision supported by other County Government Institutions; NGOs and INGOs. The Informal institutions include: The community water committees, water resource user groups and other community-led groups.

The challenges of water in Turkana are problems of governance and institutional capacity. There is "need to separate between policy, delivery and regulation, the degree of autonomy in managing service delivery, accountability as well 
as public engagement and support" [23]. Even with many existing institutions, realization of water security is hindered by gaps arising from decentralization hence the need to develop integrated strategies for the National and County Governments, and other partners to bridge the existing policy gaps and connect institutional programs to achieve the bigger goal which is water security through teamwork. The study found out that institutions are lacking needs assessment mechanisms and therefore, involvement lacks strategy and is based on availability of funds rather than needs, thus, programmatic duplication, no accountability and misappropriation of funds. This requires strategic coordination to ensure every response is strategic, need-based and pro-poor.

Coordination is essential is key in delivering water services. It is essential for all stakeholders and is a role of the county government. The government need to bring all stakeholders to dialogue and come up with a framework that will help support all actors. There is much money in this County that has come for water and other activities, but I feel part of this money ends up in people/institutions duplicating activities. So, the best would be for the County to come up with the one they were starting "County Wash". This one needs to be strengthened with regular meetings, unlike what we have now, which are ad-hoc meetings by organizations that have particular agendas such as WECOORD! It should be regular and consistent; for example, if it's quarterly, it should be that. This allows for planning and participation. (Key Informant, 2019).

The informal institutions underwater sector are there but very few and less recognized or considered in policy or strategy formulation processes. The main informal institutions underwater sector include the village water committees and water user groups. Turkana draft water policy 2016 does not highlight sufficiently the mechanisms they aim to use to involve informal institutions in water sector development however such institutions are very critical in ensuring that the social norms and values such as taboos are considered while strategizing for water resource management [16].

Overlooking traditional systems of leadership or community governance can be a recipe to project failure for institutions working on water sector development [24]. Moreover, informal institutions reinforce the formal institutions, and therefore, there is a need to intercept formal and informal institutions to enhance service delivery and thus, water security. It is through informal systems such as local community meetings (barazas) that communities are informed about in-coming projects and voted for or against it. The elders and area chiefs who are in the local groups committees call such meetings. The success of development projects extensively relies on the support of the local community leaders and community members. One of the critical informants gave a case where a water ATM project intended to ensure accountability and efficient revenue collection in Turkana-Kakuma was rejected because the community members felt their local leadership wasn't involved in planning. He explained that:

"When we introduced the ATMs, it became a huge issue.
And I remember a Baraza meeting was called (Public Community Meeting) to talk about the change to ATMs and they were almost all against the ATMs because they alleged that it was going to interfere with the operations and that the community is very vulnerable and there is no way water can be sold to them through ATMs. They fought the water ATMs, and it did not pick up." (Key informant, ID 4, 2019)

Turkana communities had social structures that offered frameworks for access to water resources, including water committees and water user associations (WUAS). These structures established regulations that ensured sustainable management of the water resources amidst of scarcity. They controlled water access to ensure misuse was met with persuasion, force or legal action. Moreover, membership to such groups was based on terms hence non-members paid fees or signed agreements before accessing water [16]. However, conflicts regularly erupted over resources, especially during droughts, when water is scarce due to high dependence on the water resources by people and livestock. Violent conflicts over water resources continue to be a problem in Turkana, and one of the avenues to solving it is engagement with informal institutions. The locals understand their problems better and have better solutions to local problems. It is essential for formal institutions ensured that projects are handed over to local communities after sufficient orientation and capacity building [24].

\section{Gaps and Opportunities}

\subsection{Gaps}

Even with involvement, many institutions in water sector development in Turkana, this study finds out that many gaps inhibit the development of the sector. Besides water quality being inadequate and insufficient, various social, institutional and economic challenges are also affecting realization of water security in this County. Water sector development rate has been slow and focusing much on urban areas rather than weak rural areas, which are experiencing acute water problems. This calls for the allocation of resources based on needs and evidence to ensure even distribution of water point across Turkana rather than clustering them in a few areas.

Political interference also affects water service provision. For example, in some parts of Turkana, the study found that some of the leaders use their positions to influence decisions without plans or assessments, thus high chances of programmatic failures. Furthermore, misappropriation of funds and corruption was also identified as a challenge hence the categorization of some institutions especially the county government institutions as high risk and other low risk by donors. Therefore donors reduced funding opportunities and tightened terms of engagement for such institutions, so that value for money is attained. This means the funding opportunities are withdrawn hence no development

The study further found out that there has been gross institutional memory loss from the time decentralization began because leadership was changed and new 
administrative systems brought into operations, under the assumption that everything was starting afresh. The county government is also struggling with the development of policies and setting up of administrative systems because the transition of functions hasn't been fully done. For a service provision sector such as the water sector, there has been a desire to have institutions involved in operations and maintenance rather than putting strategies in place first. Decisions are neither strategic nor need-based but mainly address operational and maintenance issues. This eventually has affected water service delivery.

It was realized that most partners focus mainly on software solutions rather than the much-needed hardware solutions for the water sector in Turkana. For people to realize benefits of water sector development, the hardware problems such as installation of storage systems and water supply networks such as a piping system need to be addressed even though the hardware problems need high investment levels, which only a few partners can fund. For instance, to acquire a piping system, which is hardware, a key informant in this survey pointed out that: "HDP pipes are costly. One meter of HDP PN16 pipe costs KSh1200 and therefore for 3 kilometres cost KSh 3.6 million" (Key informant, 2019). Therefore, partners showed interest mainly on small projects such as shallow wells, which are cheap, and unsustainable, yet they are spending much money on their management staff and operations. This calls for institutional vetting and provision of progress reports against work plans as discussed by partners.

The existing water distribution network in Lodwar has outlived its lifespan and cannot adequately serve the towns' water demand because its old and its design was meant for a smaller population which the current population supersedes because of the developments that have taken place over time. Furthermore, the storage tanks are not sufficient to serve the increased population. Moreover, the extreme climatic conditions such, as high temperatures and rocky terrain are a significant challenge to the pipe networks and the tanks because pipe and tank bursts are a change. This calls for improving the quality of these utilities, which comes at a very high fee. Turkana lacks a wastewater treatment facility, sewerage and drainage systems in all its towns, which are experiencing population explosion due to the current oil exploration activities. This exposes the County to water, health and sanitation risks such as the breakout of waterborne diseases including cholera, dysentery, typhoid and diarrhoea [25].

\subsection{Best Case Scenarios}

Water Insurance scheme - This is an insurance program aiming to ensure all the water points, i.e. the boreholes and hand pumps so that maintenance services are offered by Diocese of Lodwar (DOL) which is one of the organizations working on water sector. For example, if it's a hand pump, the community pays about KSh 3500 shillings, and if there is any breakdown, the DOL maintenance team repairs the borehole. If the water point is mechanized, i.e., solar-powered or generator or electricity, the team services it.
The scheme ensures water points are operational and functional at any given time. The insurance scheme now covers 400 water points in the County.

Water ATMs - Water ATM technology has dramatically increased revenues collected and accountability. The Kiosk (Water vending shop) doesn't require an attendant for one to get water. You only buy an ATM card, and you go to the water point and get water. The technology helps in decongesting the water kiosk, and people can get water at their convenience. It reduces the long queuing at the water point and long waiting times, and you don't have to pay anyone to pay the Kiosk. All the payments can be monitored through the system, and the customers redeem their cards by reloading with money before they can get water. That means improved revenue. A key informant explained that,

"In a month, the Kiosks could give KSh 15000 (USD 150) every month as revenue collected from water sales, i.e. KSH 300 (USD 3) per month per household. The total revenue could sometimes be lower because of defaults or shortages. When water ATMs was introduced, this amount increased to KSh 5000 (USD 50) - KSh 10000 (USD 100) in a week depending on the sales made by the 6 kiosks. So LOWASCO earns estimate KSh 180000 (USD 1800) on the lower side every month from the 6kiosks compared to initial KSh 15000 (USD 150) per month." (Key Informant, 2019)

Solar water pump - Solar water pump system has many advantages, and the only challenge is that its initial cost is always very high, but the operational cost is always nil once installed. Given that Turkana experiences high solar intensity, running the system is always very easy. Turkana county government through LOWASCO and NGOs such as Oxfam are using solar technology to pump water from the boreholes to the reservoir tanks. This reduces water shortage, but the challenge has been getting technicians who can service and maintain these systems during breakdowns; hence the cost of maintenance has been high. Further, windmill technology can be harnessed, but the technology has a gap in Turkana because technicians are not there.

Water Pump Scanner - A pump scanner technology is an application that was developed to enable technicians to check and monitor the performance of the boreholes. Through the pump scanner, water technicians can get the pump operations, pump operations time, whether the pump is working, whether it's broken down at any given time. It shows the particular output of the pump per month or cumulative a year. It is essential in determining the pump performance helps predict whether a borehole drawdown is reducing hence a warning as to whether we are facing drought (Key Informant, 2019)

Community Sensitization - Community sensitization on water, health and sanitation issues are very vital. In some locations in Turkana, the study found out that in areas with alternative sources of water such as a river, communities tend to decline paying the community charges of KSh 3500 (USD 35 ) for the whole community for water point maintenance services and they opt for the water that is not safe. Stakeholders within the County need to sensitize and educate the community about the difference between clean and dirty 
water and further highlight to them the risks of using untreated water so that they can appreciate paying KSh 3500 (USD 350) as a community for their family's health and safety.

"One day we visited an area after it had rained and we found out that the community had decided to lock the hand pump and use water from a hand-dug well for domestic use. They didn't want to use this hand pump because of fear that it could break down. So, they wanted to use the dirty water until it's finished, is when they come back to the pump. Therefore, sensitization and knowledge are a gap for the community members" (Key Informant, 2019).

\section{Conclusion}

The case of water governance in Lodwar, Turkana, suggests that policy changes - including political devolution, formal and information governance systems can instead exacerbate a situation of overlapping authority claims, and local competition and tension over these claims. For example, devolution of water services to county government to decentralized services was meant to bring about efficiency in services delivery, and such decentralization efforts do not necessarily lead to more socially just and efficient resource governance. Furthermore, with the realization that there were over 60 local, regional and international organizations involved in water governance, implementation of these political changes remains rife with contestations and may have unpredictable outcomes for power relations and water governance processes.

The current study has identified several sources of tension in water governance: between county-level government and other informal organizations where government, community and non-governmental organizations all claiming authority to make decisions over water; between different groups claiming authority based on customary rights to water resources and finally and between different water users including pastoral livestock use and domestic (and related users). However, the tensions may not be necessarily negative and may form part of contestations over inequitable or socially and environmentally unsustainable management decisions by certain actors which disadvantage of other users.

This study concludes that the study finds that existing institutions are working in silos and most of the programmatic responses to water problems are implemented without sufficient scientific evidence, thus the failure of water projects in providing the solution. Moreover, a policy and legal framework are still lacking to streamline coordination of the different actors to bring efficiency and equity. To some extent, given the socio-cultural and environmental conditions in Turkana, overlapping authority claims, tensions and contestations will always form part of water governance and indeed the evolution of governance with environmental change. Opening up space for constructive and inclusive dialogue is vital in coming up with inclusive water governance system that recognizes the access right of all groups including the marginalized group

\section{Acknowledgements}

First and foremost, we wish to appreciate the International Development Department (IDD) staff at the University of Birmingham for supporting the study. We give special thanks to Prof. Nicholas Cheeseman for the immeasurable support and guidance during the study. We further extend our appreciations to Dr. Tom Hewitt for the guidance and insights at the beginning of this study. A special mention needs to go to Andrea Potter for ensuring the study materials in time. We are indebted to all households and professionals in the water sector that facilitate the interviews in Turkana County. Special thanks to REACH Kenya Programme team, led by Prof Olago and Dr. Opondo.

\section{References}

[1]. Malik, Nightingale, A. J. and Ojha, H. R. (2013). Rethinking power and authority: symbolic violence and subjectivity in Nepal's Terai forests. Development and Change, 44, 29-51.

[2]. Nightingale, A. J. (2018). The socioenvironmental state: Political authority, subjects, and transformative socionatural change in an uncertain world. Nature and Space E. 1, 688-711.

[3]. Kanda, E., Taragon, J., Waweru S. et al. (2013) the Water Act 2002 and the Constitution of Kenya 2010: Coherence and Conflicts towards Implementation. Masinde Muliro University of Science and Technology.

[4]. Paavola, J. (2007). Institutions and environmental governance: A reconceptualization. Ecological Economics 63 (1) 93-103.

[5]. Lemos, M. C. and Agrawal, A. (2006). Environmental governance. Annu. Rev. Environ. Resour. 31, 297-325.

[6]. Nightingale, A. J. (2017). Power and politics in climate change adaptation efforts: Struggles over authority and recognition in the context of political instability. Geoforum $84,11-20$.

[7]. Eriksen, S. H., Nightingale, A. and Eakin, H. 2015. Reframing adaptation: the political nature of climate change adaptation. Global Environmental Change, 35, 523-533.

[8]. Ribot, J. C. 2003. Democratic decentralization of natural resources: Institutional choice and discretionary power transfers in sub-saharan Africa. Public Administration and Development 23, 53-65.

[9]. Coultier, J. E., Witinok-Huber, R. A., Bruyere, B. L., Nyingi, W. D. 2019. Giving women a voice on decision-making about water: barriers and opportunities in Laikipa, Kenya. Gender, Place and Culture 26, 489-509.

[10]. REACH (2015) Country Diagnostic Report, Kenya. REACH Working Paper 3, University of Oxford, Oxford, UK.

[11]. MoWI, 2006. The National Water Resources Management Strategy (NWRMS), 2006-2008.

[12]. Saravanan, V. S., McDonald, G. T. and Mollinga, P. P. (2009). Critical review of Integrated Water Resources Management, Natural Resources Forum Report. Natural Resources Forum 33 (2009) 76-86. 
[13]. Water Resources Group, 2015. Water Resources in Kenya: Closing the Gap. Briefing Notes. https://www.2030wrg.org/wp-content/uploads/2014/07/Kenya-Hydro-Econ omic-Briefing-Note_May2015.pdf.

[14]. D'Arcy, M. Cornell, A. 2016: Devolution and Corruption in Kenya: Everyone's Turn to Eat? African Affairs, 115/459, PP. 246-273. Oxford University Press. doi: 10.1093/afraf/adw002.

[15]. Cheeseman, N., Lynch, G. and Willis, J. (2016). Decentralization in Kenya: the governance of governors. The Journal of Modern African Studies, 54, pp 1-35 doi: $10.1017 / \mathrm{S} 0022278 \mathrm{X} 1500097 \mathrm{X}$.

[16]. TCG, 2016. The Turkana County Water and Sewerage Services Sector Policy.

[17]. Mack, N., Woodsong, C., and MacQueen, K, et al. (2005) Qualitative Research Methods: A Data Collector's Field Guide. North Carolina: Family Health International.

[18]. Rahman, S. (2016). The Advantages and Disadvantages of Using Qualitative and Quantitative Approaches and Methods in Language "Testing and Assessment" Research: A Literature Review. Journal of Education and Learning; Vol. 6, No. 1.

[19]. Alexa Hepburn and Galina B. Bolden, 2017. Transcribing for social research. Sage Publications.
[20]. Millennium Water Alliance, 2018. Turkana County Capacity Needs Assessment Report. Water Sector. Bridge Africa ADC.

[21]. Olago, O. O. (2018), Constraints and solutions for groundwater development, supply and governance in urban areas in Kenya. Hydrogeology Journal. Accessible from: https://doi.org/10.1007/s10040-018-1895-y.

[22]. Haines, S., Imana, C. A., Opondo, M., Ouma, G. and Rayner, S. (2017) Weather and climate knowledge for water security: Institutional roles and relationships in Turkana. REACH Working Paper 5, University of Oxford, Oxford, UK.

[23]. Koehler, J., Rayner, S., Katuva, J., Thomson, P. and Hope, R. (2018) A cultural theory of drinking water risks, values and institutional change. Global Environmental Change, 50: 268-277.

[24]. Derman, B., Hellum, A., Manzungu, E., Sithole, P., and Machiridza, R. (2007), Community-based water law and water resources management reform in developing countries, Cambridge International.

[25]. Intelligence Community Assessment (2012), Global Water Security, ICA. 